\title{
THE PROFILE OF STUDENTS' LEARNING STYLES AND THEIR EFFECTS ON GRADE POINT AVERAGE (GPA) ACHIEVEMENT
}

\section{PROFIL GAYA BELAJAR MAHASISWA DAN PENGARUHNYA TERHADAP KETERCAPAIAN INDEKS PRESTASI KUMULATIF}

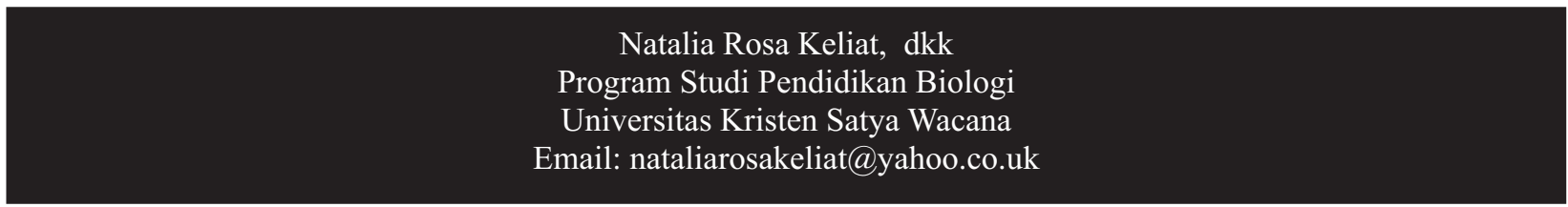

\begin{abstract}
Learning style is one of the important factors needed to absorb, store and process the new information. This research is a study to see the profile and percentage of studenst learning styles of SWCUBiology Education students and the influence of different learning styles on the GPA obtained. Researcher got the data of students' learning styles by using questionnaire. The statistical procedures employed in this study were one-way ANOVA. The results showed that the largest percentage of learning styles that were used by the students of biology education were auditory learning styles by 32\% and the VAK (Visual Auditory Kinesthetic) learning style was the least used by education students by $2 \%$. The analysis of the percentage oflearning styles showed that $72 \%$ of students with auditory learning styles reached a satisfactory category until magna cum laude, but the percentage of students that used VAK (Visual Auditory Kinesthetic) learning styles only reached satisfying GPA level. Statistical test results in this study demonstrated that the use of learning styles did not give significantly different effect on the students' GPA.
\end{abstract}

\section{Keywords: Personal Learning Styles, Grade Point Average}

Abstrak, Gaya belajar adalah salah satu faktor penting yang diperlukan untuk menyerap, menyimpan dan memproses informasi baru. Penelitian ini adalah suatu penelitian untuk melihat profil dan persentase gaya belajar mahasiswa pendidikan biologi UKSW serta pengaruh gaya belajar yang berbeda terhadap indeks prestasi kumulatif yang diperoleh. Peneliti mendapatkan data gaya belajar mahasiswa dengan menggunakan kuesoner (angket). Prosedur statistik yang digunakan dalam penelitian ini adalah one way ANOVA. Hasil penelitian menunjukkan bahwa persentase gaya belajar terbesar yang digunakan mahasiswa pendidikan biologi untuk belajar adalah gaya belajar auditorik sebanyak $32 \%$, Persentase gaya belajar yang paling sedikit digunakan oleh mahasiswa pendidikan adalah gaya belajar VAK (Visual Auditorik Kinestetik) sebanyak 2\%. Analisis persentase gaya belajar menunjukkan persentase mahasiswa pendidikan biologi dengan gaya belajar auditorik adalah yang terbanyak memiliki IPK yang termasuk dalam kategori memuaskan sampai magna cum laude sebesar $72 \%$, namun ternyata persentase mahasiswa dengan gaya belajar VAK (Visual Auditorik Kinestetik) tidak mencapai IPK memuaskan, dan hanya mencapai level kurang. Hasil uji statistik dalam penelitian ini menunjukkan penggunaan gaya belajar tidak memberikan pengaruh yang berbeda secara signifikan terhadap indeks prestasi kumulatif mahasiswa.

Kata Kunci : Gaya Belajar, Indeks Prestasi Kumulatif

\section{A. PENDAHULUAN}

Gaya belajar dan berpikir bukanlah kemampuan, tetapi cara yang dipilih seseorang untuk menggunakan kemampuannya, Drysdale, Ross \& Schults dalam Santrock (2007). Kolb dan Honey (1984) dan Mumford (1992) dalam Abidin (2011) menggambarkan gaya belajar sebagai cara yang disukai individu atau kebiasaan pengolahan dan transformasi pengetahuan. Lebih lanjut menurut Kolb atribut psikologis, akibat perbedaan individu, menentukan strategi tertentu seseorang memilih cara belajar. Di sisi lain, Keefe dalam Abidin (2011) menekankan gaya belajar 
cenderung memperoleh lebih banyak dan mendapatkan skor yang lebih tinggi dibandingkan dengan pembelajar yang hanya mengandalkan satu gaya (Dunn, Beaudry \& Klavas dalam Abidin, 2011).

Hal ini bertolak belakang dengan hasil penelitian Nafif \& Fetty (2012) yang menyatakan bahwa secara parsial gaya belajar visual, gaya belajar audio dan gaya belajar kinestetik berpengaruh positif dan signifikan terhadap prestasi belajar mahasiswa, artinya apabila gaya belajar visual, audio dan kinestetiknya rendah, maka prestasi akademik mahasiswa juga akan menurun, begitu pula sebaliknya, jika gaya belajar visual, audio dan kinestetiknya tinggi maka prestasi belajar mahasiswa juga akan meningkat. Nafif \& Fetty (2012) menyebutkan bahwa gaya belajar visual, audio dan kinestetik berpengaruh signifikan terhadap prestasi akademik mahasiswa.

Gaya belajar merupakan salah satu faktor penting yang mampu mempengaruhi prestasi akademik pembelajar, akan tetapi dewasa ini penerapan gaya belajar yang sesuai dengan pembelajar sering terlupakan. Untuk itu, peneliti akan mengkaji dan menganalisis profil gaya belajar mahasiswa program studi pendidikan biologi serta pengaruhnya bagi prestasi akademik yang diperoleh mahasiswa.

Adapun tujuan penelitian yang ingin dicapai dalam penelitian ini adalah sebagai berikut:

1. Untuk mengetahui profil gaya belajar mahasiswa Program studi pendidikan biologi UKSW.

2. Untuk mengetahui persentase gaya belajar mahasiswa Program studi pendidikan biologi UKSW.

3. Untuk mengetahui apakah terdapat pengaruh gaya belajar terhadap indeks prestasi akademik (IPK) mahasiswa Program studi pendidikan biologi UKSW.

Dengan diperolehnya hasil penelitian sesuai tujuan di atas diharapkan memberikan manfaat bagi pembelajar berupa pengetahuan sehingga mampu mengelola gaya belajar yang sesuai dengan kepribadiannya dan mampu mengoptimalkan potensi gaya belajar yang dimiliki sehingga mencapai prestasi akademik yang baik. Selain itu diharapakan penelitian ini memberikan pegetahuan bagi dosen/guru untuk mengoptimalkan pembelajaran di kelas sehingga mampu memfasilitasi setiap pembelajar yang memiliki gaya belajar yang berbeda-beda.

Metode penelitian yang digunakan dalam penelitian ini yaitu metode deskriptif melalui perhitungan persentase gaya belajar yang digunakan oleh mahasiswa dan menggunakan uji ione way Anova untuk melihat pengaruh penggunaan gaya belajar tersebut terhadap indeks prestasi kumulatif yang dicapai oleh mahasiswa.

\section{B. HASIL DAN PEMBAHASAN}

Data penelitian diperoleh dengan menggunakan kuesioner yang akan dibagikan kepada mahasiswa program studi pendidikan biologi UKSW. Selain itu, data penelitian juga diperoleh dari data Indeks Prestastasi Kumulatif (IPK) mahasiswa program studi pendidikan biologi UKSW. 
sebagai kognitif, afektif, dan sifat-sifat psikologis yang berfungsi sebagai indikator relatif stabil dari bagaimana peserta didik mempersepsikan, berinteraksi dan menanggapi lingkungan belajar. Gaya belajar merupakan salah satu faktor internal penunjang hasil belajar individu sehingga dapat optimal.

Penelitian tentang gaya belajar didasarkan pada teori bahwa individu memilih gaya belajar mereka sendiri untuk untuk menyerap, menyimpan dan memproses informasi baru . Cassidy \& Eachus, 2000; Dunn, 1983; Harrison, Andrews, \& Saklofske, 2003 dalam Moussa (2014).

Menurut Ken dan Rita dalam penelitiannya dalam Rose \& Malcolm (2003) ada tiga gaya belajar dan komunikasi yang dilakukan oleh manusia: (1) Visual merupakan belajar melalui melihat sesuatu; (2) Auditori merupakan belajar melalui mendengar sesuatu; (3) Kinestetik merupakan belajar melalui aktivitas fisik dan keterlibatan langsung.

Chong-Cheng dalam Abidin (2011) membahas pentingnya gaya belajar bagi pembelajar dalam pengaturan akademik. Kebanyakan pembelajar lebih memilih untuk belajar dengan cara tertentu dengan gaya belajar masing-masing yang memberikan kontribusi bagi keberhasilan pembelajaran dan dalam mempertahankan apa yang telah dipelajari. Hardiansyah (2014) dalam penelitiannya menyebutkan bahwa pembelajar yang menggunakan model gaya belajar visualkinstetik mempunyai prestasi akademik yang lebih baik dibandingkan mahasiswa yang menggunakan satu jenis gaya belajar. Lebih lanjut Hardiansyah (2014) dan Nihayah (2011) dalam penelitiannya menyatakan pembelajar yang memiiki hanya satu jenis gaya belajar tidak berpengaruh terhadap pencapaian indek prestasi kumulatif.

Berdasarkan hasil penelitian Hardiansyah dan Nihayah terlihat bahwa prestasi akademik pembelajar yang mengunakan kolaborasi beberapa gaya belajar lebih baik dibandingkan dengan pembelajar yang hanya menggunakan satu jenis gaya belajar. Penggabungan beberapa jenis gaya belajar akan melibatkan lebih banyak indera dalam proses pmbelajaran dan akan mampu meningkatkan pemahaman suatu materi.

Pembelajar sukses memiliki berbagai cara belajar yang berbeda, namun memiliki kesamaan dalam hal penggunaan pedekatan aktif terhadap pembelajaran. Pembelajar aktif senantiasa bertanya kepada diri sendiri serta melakukan sesuatu untuk meyakinkan diri telah mendapatkan fakta-fakta dalam cara yang sesuai dengan inderanya. Chong-Cheng dalam Abidin (2011) menyimpulkan bahwa pembelajar mempertahankan $10 \%$ dari apa yang dibaca, $26 \%$ dari apa yang didengar, 30\% dari apa yang dilihat, 50\% dari apa yang dilihat dan didengar, 70\% dari apa yang dikatakan, dan $90 \%$ dari apa yang dikatakan ketika melakukan sesuatu. Fakta-fakta ini menunjukkan bahwa setiap gaya belajar memiliki kekuatan dan kelemahan sendiri. Beberapa pembelajar mampu belajar dalam banyak cara, sementara yang lain mungkin hanya menggunakan satu atau dua cara. Pembelajar dengan beberapa gaya belajar 
Pengelompokkan IPK mahasiswa berdasarkan sistem kredit UKSW yang terdapat dalam peraturan penyelenggaraan kegiatan akademik adalah sebagai berikut:

\section{Gaya Belajar Mahasiswa}

Tabel 2.1 Kategori Pengelompokkan IPK

\begin{tabular}{cc} 
Jenjang & Predikat \\
IPK & \\
\cline { 2 - 2 }$<2,00$ & Kurang \\
$2,00-2,49$ & Cukup \\
$2,50-2,74$ & Baik \\
$2,74-2,99$ & Memuaskan \\
$3,00-3,49$ & Sangat memuaskan \\
$3,50-3,74$ & Terpuji (Cum Laude) \\
$3,75-3,99$ & Lebih dari terpuji (Magna \\
& Cum Laude) \\
$=4,00$ & Sangat terpuji (Summa \\
& Cum Laude) \\
\cline { 2 - 2 }
\end{tabular}

Berdasarkan hasil penelitian yang dilakukan grafik berikut ini: pada semua mahasiswa pendidikan biologi diperoleh data persentase gaya belajar yang disajikan dalam

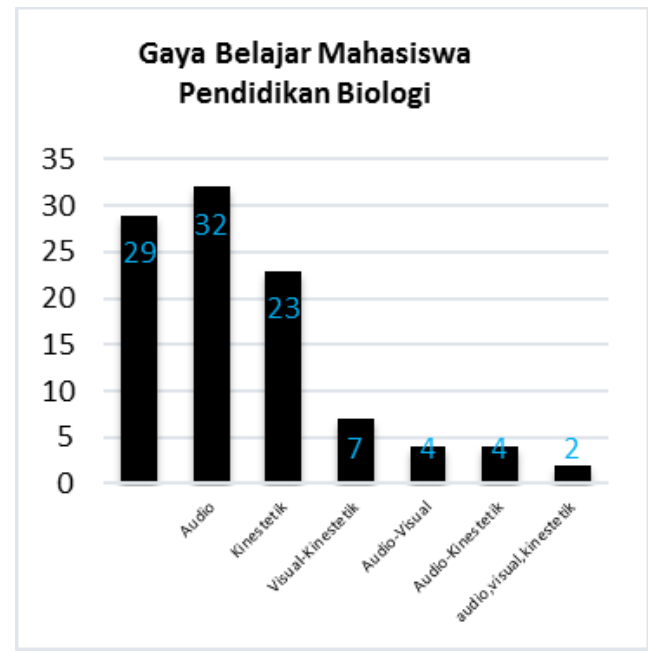

\section{Gambar 2.1 Grafik Persentase Gaya Belajar Mahasisiwa Pendidikan Biologi UKSW}

Gambar 1. Grafik persentase gaya belajar mahasiswa pendidikan biologi UKSW di atas menunjukkan bahwa persentase mahasiswa yag menggunakan gaya belajar visual mencapai $29 \%$, yang menggunakan gaya belajar audio mencapai $32 \%$, yang menggunakan gaya belajar kinestetik mencapai $23 \%$, yang menggunakan gaya belajar visual-kinestetik mencapai $7 \%$, yang menggunakan gaya belajar audio-visual mencapai $4 \%$, yang menggunakan gaya belajar audiokinestetik mencapai 4\%, yang menggunakan gaya belajar visual-audio-kinestetik hanya mencapai 
$2 \%$,

Berdasarkan hasil penelitian per angkatan diperoleh data persentase gaya belajar mahasiswa pendidikan biologi UKSW per angkatan yang disajikan dalam grafik berikut ini:

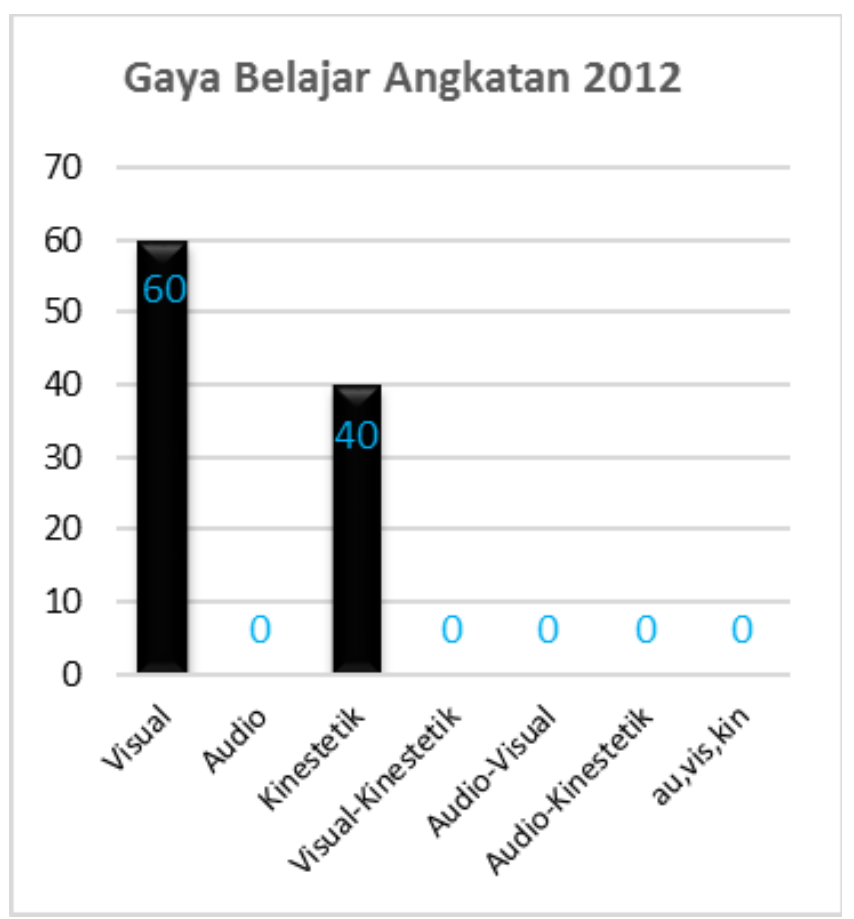

\section{Gambar 2.2 Grafik Persentase Gaya Belajar Mahasisiwa Angkatan 2012}

Gambar 2. Grafik persentase gaya belajar mahasiswa pendidikan biologi UKSW angkatan 2012 menunjukkan bahwa persentase mahasiswa yang menggunakan gaya belajar visual mencapai $60 \%$, yang menggunakan, yang menggunakan gaya belajar kinestetik mencapai $40 \%$, yang menggunakan gaya belajar gaya belajar audio, gaya belajar visualkinestetik, gaya belajar audio-kinestetik, gaya belajar visual-audio-kinestetik dan gaya belajar audio-visual hanya mencapai $0 \%$.

Gambar 2.3 Grafik persentase gaya belajar

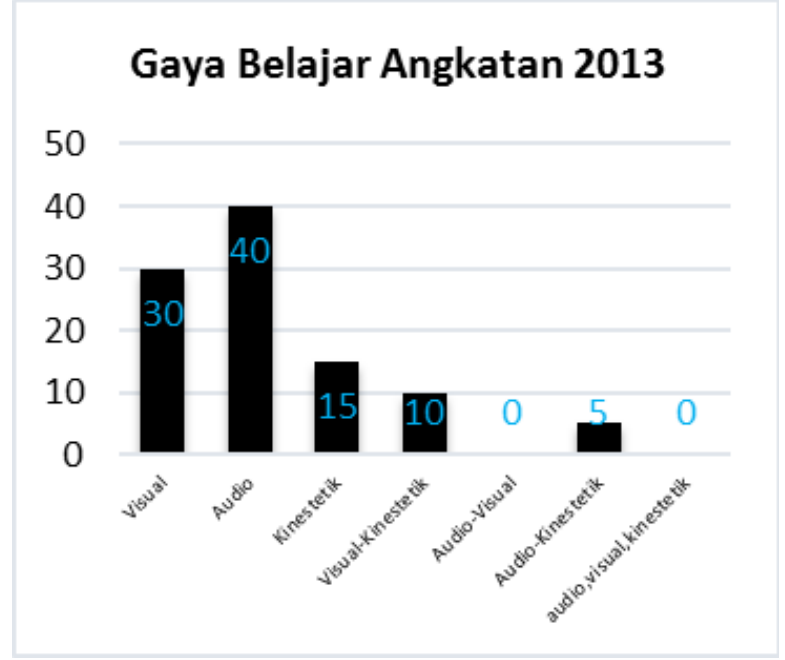

Gambar 2.3 Grafik Persentase Gaya Belajar Mahasisiwa Angkatan 2013 
mahasiswa pendidikan biologi UKSW angkatan 2014 menunjukkan bahwa persentase mahasiswa yag menggunakan gaya belajar visual mencapai $25 \%$, yang menggunakan gaya belajar audio mencapai $40 \%$, yang menggunakan gaya belajar kinestetik mencapai $20 \%$, yang menggunakan gaya belajar visual-kinestetik, gaya belajar audio-visual, gaya belajar visual-audio-kinestetik hanya mencapai 5\% dan yang menggunakan gaya belajar audio-kinestetik hanya $0 \%$.

Gambar 2.4 Grafik persentase gaya belajar

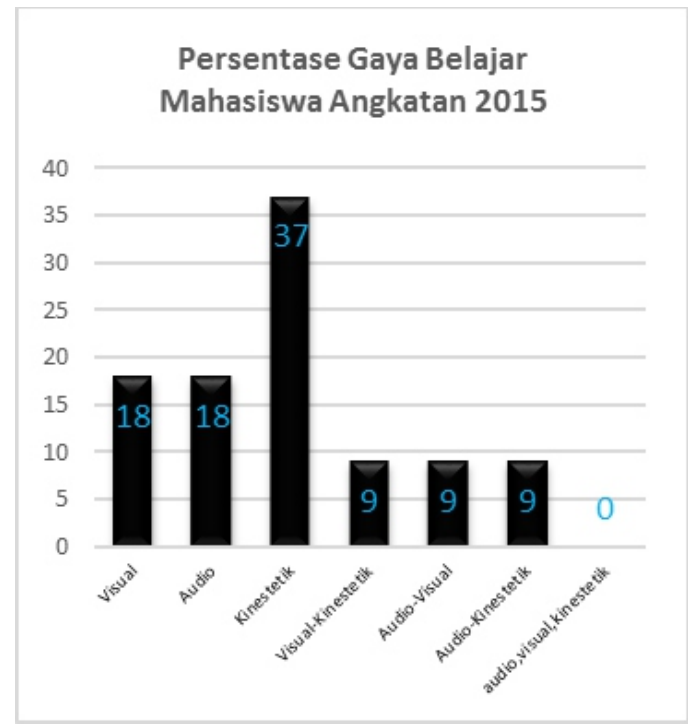

\section{Gambar 2.4 Grafik Persentase Gaya Belajar Mahasisiwa Angkatan 2015}

mahasiswa pendidikan biologi UKSW angkatan 2015 menunjukkan bahwa persentase mahasiswa yag menggunakan gaya belajar visual mencapai $18 \%$, yang menggunakan gaya belajar audio mencapai $18 \%$, yang menggunakan gaya belajar kinestetik mencapai $37 \%$, yang menggunakan gaya belajar visual-kinestetik, gaya belajar audio-visual, gaya belajar audio-kinestetik hanya mencapai $9 \%$, yang menggunakan gaya belajar visual-audio-kinestetik hanya mencapai $0 \%$.

Gaya belajar visual (visual learner) menitikberatkan ketajaman penglihatan Artinya, bukti-bukti konkret harus diperlihatkan terlebih dahulu agar siswa paham (Nihayah, 2011). Proses visual dapat dilakukan secara internal dan eksternal. Seorang pembelajar visual memilih untuk melihat segala sesuatu secara internal dalam benaknya sebelum menggambarkan atau mendiskusikan dengan orang lain (Russel, 2011). Seorang pembelajar visual yang lebih eksternal suka melihat segala sesuatu, petunjuk, computer, buku seni. Bukan hal yang mengejutkan jika ditemukan fakta bahwa $70 \%$ dari reseptor indera (sensori) berada dimata. Untuk menyerap cahaya, retina memiliki 120 juta batang saraf dan 7 juta kerucut saraf. Masing-masing batang saraf atau kerucut saraf mata memusat pada suatu bagian kecil spesifik medan visual.

Auditorial berasal dari kata audio yang berarti sesuatu yang berhubungan dengan pendengaran. Gaya belajar auditorial merupakan gaya belajar dengan cara mendengar. Karakteristik gaya belajar 
seperti ini menempatkan pendengaran sebagai alat utama menyerap informasi atau pengetahuan. Artinya, harus mendengar, baru kemudian dapat mengingat dan memahami informasi tertentu (Nihayah, 2011). Ketika pembelajar auditoris eksternal berbicara, mereka akan melakukannya dengan lambat, dengan irama terukur yang dapat diinterpretasikan oleh pembelajar lain sebagai lambat dan monoton. Namun terdapat irama yang jelas dalam suara mereka yang mereka nikmati dengan cara mendengarkan. Seorang pembelajar dengan kecenderungan auditoris dapat memfokuskan diri secara internal maupun eksternal. Pembelajar auditoris eksternal bahkan mungkin berbicara pada diri mereka sendiri ketika tengah belajar. Sementara pembelajar auditoris eksternal akan berkata pada dirinya sendiri didalam kepalanya, namun jika dilihat dari luar satu-satunya kebiasaan yang terlihat adalah kesunyian (Russel,
2011).

Seorang pembelajar dengan kecenderungan kinestetik merupakan seorang pembicara yang sangat fisikal dan banyak berbicara dengan bahasa tubuh serta gerakan seperti halnya dengan kata-kata (Russel, 2011). Seorang pembelajar kinestetik dapat mewujudkan dirinya sendiri secara internal dan eksternal. Pembelajar kinestetik lebih menyukai sentuhan fisik, belajar dengan cara mencoba sesuatu dengan tangan mereka dan kemudian banyak sekali membuat catatan selama proses pembelajaran berlangsung.

\section{Indeks Prestasi Kumulatif pada Setiap Gaya Belajar}

Berikut ini adalah pengelompokkan data Indeks prestasi kumulatif mahasiswa berdasarkan gaya belajar.

Berdasarkan keterangan tabel 2.2 Diperoleh

Tabel 2.2 Persentase indeks prestasi kumulatif mahasiswa berdasarkan gaya belajar mahasiswa

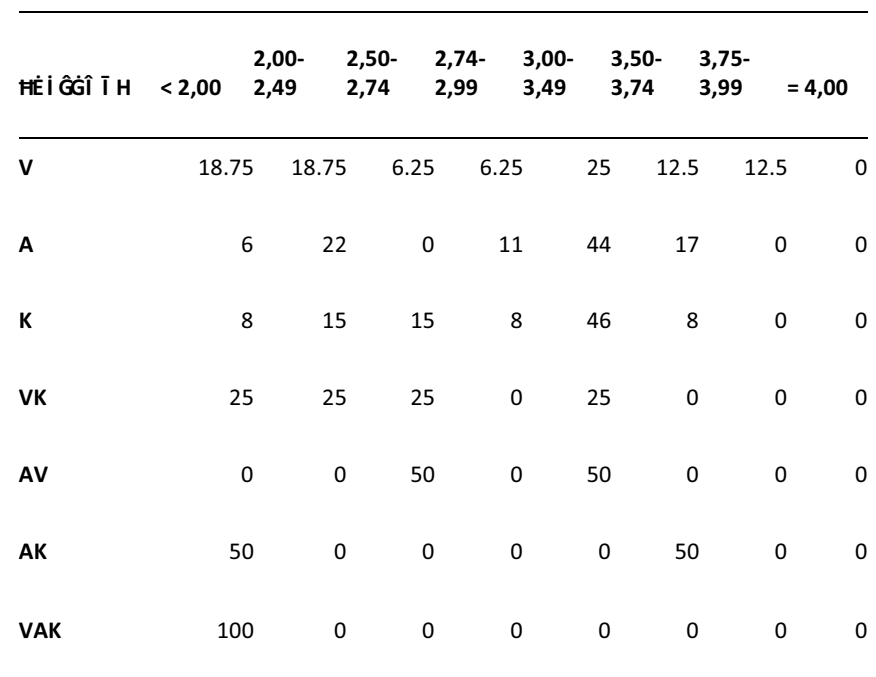

data mahasiswa pendidikan biologi UKSW yang memiliki IPK memuaskan sampai magna cum laude sebanyak $56.25 \%$ yang bergaya visual, $72 \%$ yang bergaya belajar auditorik, $62 \%$ yang bergaya belajar kinestetik, 25\% yang bergaya belajar visual kinestetik, $50 \%$ yang bergaya belajar auditorik visual, $50 \%$ yang bergaya belajar auditorik kinestetik dan o\% yang bergaya belajar visual 
auditorik kinestetik. Dari data tersebut dapat dilihat bahwa persentase jumlah mahasiswa auditorik memiliki IPK terbesar dalam kategori IPk memuaskan sampai magna cum laude.

Pada tabel 3 dapat dilihat nilai mean IPK

Tabel 2.3 Mean, Standar deviasi dan median indeks prestasi kumulatif ahasiswa berdasarkan gaya belajar

\begin{tabular}{|c|c|c|c|}
\hline Gaya belajar & Ì ÑNō & $\pm S D$ & Median \\
\hline Visual & 2.7975 & 0.876801 & 2.905 \\
\hline Auditorik & 2.930556 & 0.65325 & 3.165 \\
\hline Kinestetik & 2.818462 & 0.785927 & 3.08 \\
\hline \multicolumn{4}{|l|}{ Visual } \\
\hline Kinestetik & 2.35 & 0.847073 & 2.395 \\
\hline \multicolumn{4}{|l|}{ Visual } \\
\hline Auditorik & 2.945 & 0.487904 & 2.945 \\
\hline \multicolumn{4}{|l|}{ Auditorik } \\
\hline Kinestetik & 2.3 & 1.725341 & 2.3 \\
\hline \multicolumn{4}{|l|}{ Visual } \\
\hline Kinestetik & 1.78 & 0 & 1.78 \\
\hline
\end{tabular}

tertinggi dimiliki oleh mahasiswa yang kelompokvisual auditorik kinestetik sebesar 1.78. menggunakan gaya belajar auditorik sebesar 2.930, sedangkan nilai mean IPK terendah dimiliki oleh

Tabel 2.4 Hasil uji one way ANOVA

\begin{tabular}{|l|r|r|r|r|r|}
\hline \multicolumn{5}{|c|}{ Tests of Between-Subjects Effects } \\
\hline Dependent Variable: IPK & \multicolumn{1}{|c|}{ Sig. } \\
\hline Source & $\begin{array}{l}\text { Type III } \\
\text { Sum of } \\
\text { Squares }\end{array}$ & df & $\begin{array}{c}\text { Mean } \\
\text { Square }\end{array}$ & \multicolumn{1}{l|}{ F } & Sig \\
\hline $\begin{array}{l}\text { Corrected } \\
\text { Model }\end{array}$ & $2.687^{\mathrm{a}}$ & 6 & .448 & .695 & .655 \\
\hline Intercept & 131.363 & 1 & 131.363 & 203.91 & .000 \\
\hline GAYABEL & 2.687 & 6 & .448 & .695 & .655 \\
\hline Error & 31.566 & 49 & .644 & & \\
\hline Total & 467.822 & 56 & & & \\
\hline $\begin{array}{l}\text { Corrected } \\
\text { Total }\end{array}$ & 34.252 & 55 & & & \\
\hline a. R Squared $=.078$ (Adjusted R Squared $=-.034)$ & \\
\hline
\end{tabular}


Tabel 4 uji one way ANOVA menunjukkan penggunaan gaya belajar tidak memberikan pengaruh yang berbeda secara signifikan terhadap indeks prestasi kumulatif mahasiswa.

Indeks prestasi kumulatif mahasiswa dipengaruhi oleh faktor eksternal dan internal. Faktor eksternal diantaranya adalah lingkungan keluarga, lingkungan pergaulan, kurikulum, sedangkan faktor internal yang mempengaruhi indeks prestasi kumulatif mahasiswa diantaranya adalah intelegensia atau kecerdasan, bakat, minat dan motivasi belajar. Selain itu pendekatan mahasiswa terhadap tugas menentukan sejauh mana mahasiswa terlibat dengan subjek dan mempengaruhi hasil belajar. Pendekatan dalam (deep approach) terhadap belajar ditandai dengan keinginan untuk memahami dan mencari makna, yang mendorong mahasiswa untuk mencoba menghubungkan konsep-konsep dengan pemahaman yang sudah ada dan dengan satu sama lain., membedakan antara ide-ide baru dan pengetahuan yang sudah ada, dan secara kritis mengevaluasi dan menentukan tema-tema dan konsep-konsep kunci. Pendekatan permukaan (surface approach) terhadap belajar ditandai dengan keinginan untuk menyelesaikan tugas, menghafal informasi, tidak membeda-bedakan antara ide-ide baru dan pengetahuan yang sudah ada, dan memperlakukan tugas sebagai yang dipaksakan dari luar.

Knowles dalam Popoola \& Constance (2014) berteori bahwa jika diberi kesempatan, orang dewasa lebih memilih untuk menjadi peserta aktif dalam semua tahapan proses pembelajaran dan pembelajaran mandiri memberikan kesempatan ini, mendorong siswa untuk menjadi proaktif, pelajar seumur hidup. Knowles mengidentifikasi enam prinsip dasar dan aplikasi mengenai pelajar dewasa: (1) Kebutuhan akan rasa ingin tahu; (2) Pembelajaran secara langsung; (3) Pengalaman Sebelumnya; (4) Kesiapan untuk Belajar; (5) Orientasi Belajar dan Pemecahan Masalah; dan (6) Motivasi untuk Belajar.

Motivasi belajar merupakan dorongan yang menyebabkan seorang melakukan suatu tindakan belajar. Terdapat 3 jenis motivasi: motivasi instrinsik, ekstrinsik dan motivasi berprestasi. Pintrich dan Garcia dalam Fry, Steve \& Stephanie, (2013) menemukan bahwa mahasiswa bermotif intrinsik menggunakan rencana yang direncanakan untuk mengembangan pemahaman konseptual atas materi, namun mahasiswa bermotif ekstrinsik menggunakan lebih banyak strategi latihan. Mahasiswa dengan motivasi berprestasi melakukan pendekatan strategis yang berbeda-beda tergantung kepada keadaan. Tujuan utamanya adalah untuk memperoleh nilai yang tinggi dan mahasiswa tipe ini menyesuaikan strategi untuk mencapai tujuan.

Menurut Sari (2014), ada beberapa karakteristik pembelajaran yang cocok digunakan bagi pembelajar visual; (a). guru/dosen berdiri tenang dan menyajikan segmen informasi dan bergerak perlahan pada segmen tersebut, (b). memberikan dorongan kepada pembelajar untuk menggambarkan informasi, symbol dan gambar diberikan berwarna dalam catatan siswa, (c). membuat tabel dan grafik untuk memperdalam pemahaman pembelajar visual terutama dalam bidang matematika dan IPA, (d). membuat peta pikiran/peta konsep, (e). menggunakan simbol visual dalam memberikan gambaran keseluruhan suatu konsep, (f). menggunakan bahasa simbol 
visual dalam presentasi yang dilakukan dosen, (g). memperhatikan penerangan atau pencahayaan ruang saat pembelajaran berlangsung, (h). menggunakan media pembelajaran berupa buku, flow chart, highlighting, pemajangan kata kunci dengan tulisan yang menarik.

Karakteristik pembelajaran yang sesuai digunakan bagi pembelajar yang memiliki gaya belajar auditorial menurut Sari (2014) adalah sebagai berikut: (a) Memberikan informasi secara berulang-ulang, dan dapat juga menggunakan metode tanya jawab; (b) Menggunakan teknik pengulangan, meminta pembelajar menyebutkan kembali konsep dan petunjuk; (c)Menggunakan variasi vocal dalam presentasi; (d) Menyanyikan konsep kunci; (e) Memberikan dorongan kepada pembelajar untuk membuat jembatan keledai untuk mempermudah menghafalkan/mengingat konsep kunci; (f) Menggunakan teknik tanya jawab,kerja kelompok; (g) Melibatkan music dalam pembelajaran. Lebih lanjut menurut Sari (2014), karakteristik pembelajaran yang sesuai digunakan bagi pembelajar yang memiliki gaya belajar kinestetik adalah sebagai berikut: (a) Memberikan tugas berupa proyek terapan; (b) Menggunakan media dan alat bantu yang menekankan konsep; (c) Mengijinkan pembelajar berjalan di kelas; (d) Memperagakan konsep sambil memberikan kesempatan kepada pembelajar untuk mempelajari langkah demi langkah; (e) Menciptakan simulasi konsep agar mahasiswa mengalaminya; dan (f) Membuat peta pikiran dengan melibatkan aktivitas fisik.

\section{SIMPULAN}

Hasil penelitian menunjukkan bahwa bahwa persentase gaya belajar terbesar yang digunakan mahasiswa pendidikan biologi UKSW untuk belajar adalah gaya belajar auditorik sebanyak 32\%, 29\% mahasiswa menggunakan gaya belajar visual dan $23 \%$ mahasiswa menggunakan gaya belajar kinestetik. Persentase gaya belajar yang paling sedikit digunakan oleh mahasiswa pendidikan adalah gaya belajar VAK (Visual Auditorik Kinestetik) sebanyak $2 \%$.

Dalam penelitian ini juga disimpulkan bahwa persentase mahasiswa pendidikan biologi UKSW dengan gaya belajar auditorik adalah yang terbanyak memiliki IPK yang termasuk dalam kategori memuaskan sampai magna cum laude sebesar $72 \%$, namun ternyata persentase mahasiswa dengan gaya belajar VAK (Visual Auditorik Kinestetik) tidak mencapai IPK memuaskan, dan hanya mencapai level kurang.

Dari hasil uji one way ANOVA diperoleh kesimpulan bahwa penggunaan gaya belajar tidak memberikan pengaruh yang berbeda secara signifikan terhadap indeks prestasi kumulatif mahasiswa. Berdasarkan studi literatur terhadap hasil penelitian ditemukan fakta bahwa indeks prestasi kumulatif mahasiswa dipengaruhi oleh beberapa faktor. Faktor eksternal dan faktor internal mahasiswa. Pembelajar sukses memiliki berbagai cara belajar yang berbeda, namun memiliki kesamaan dalam hal penggunaan pedekatan aktif terhadap pembelajaran. Pembelajar aktif senantiasa bertanya kepada diri sendiri serta melakukan sesuatu untuk meyakinkan diri telah mendapatkan fakta-fakta dalam cara yang sesuai dengan inderanya.

\section{DAFTAR PUSTAKA}

Abidin, M.J.Z et all. (2011), Learning Styles and Overall Academic Achievement in a Specific 
Educational System. International Journal of Humanities and Social Science. Vol. 1 No. 10; Agustus 2011 . D i a m bil d a ri http://www.ijhssnet.com/journals/Vol_1_No_10_A ugust 2011/19.pdf

Fry h, Steve K \& Stephanie. M. (2013). Teaching and Handbook. Strategi Peningkatan Mutu Pendidikan di Perguruan Tinggi. Riau: Zanafa Publishing.

Hardiansyah. (2014). Pengaruh Gaya Belajar Terhadap Prestasi Akademik Mahasiswa Fakultas Kedokteran. Jurnal Media Medika Muda. Diambil dari http\%3A\%2F\%2Feprints.undip.ac.id.

Moussa, N.M. (2014). The Importance of Learning Styles in Education. Institute for Learning Styles Journal Volume 1, Fall 2014 . Diambil d a http://www.auburn.edu/academic/education/il srj/Journal

Nazif, I \& Fetty PS \& SS. (2012). Pengaruh Gaya Belajar Terhadap Prestasi Belajar (Studi Kasus di Prodi MBTI Institut Manajemen Te $(k \circ \mathrm{m})$. D i a m b i 1 a r i https\%3A\%2F\%2Fopenlibrary.telkomunivers ity.ac.id (Diakses pada tanggal 20 Juli 2106).

Nihayah, F. (2011). Profil Gaya Belajar (Learning Style) dan IPK Mahasiswa Jurusan Biologi FMIPA UNNES. Semarang: Universitas Negeri $\mathrm{S}$ e $\mathrm{m}$ a $\mathrm{r}$ a $\mathrm{ng}$. D i a m b i 1 a $\mathrm{r}$ i http\%3A\%2F\%2Flib.unnes.ac.id.

Popoola, A.A \& Constance S.H. (2014). Learning Styles of First- Semester Baccalaureate Nursing Students: A Literature Review. Institute for Learning Styles Journal Volume 1, Fall 2014 . D i a mbil dari http://www.auburn.edu/academic/education /ilsrj/Journal

Rose, C \& Malcolm J.N. (2003). Accelerated Learning for The $21^{\text {st }}$ Century. Penerbit Nuansa

Russel,L. (2011). The Accelerated Learning Fieldbook. Nusamedia

Santrock, J. (2005). Psikologi Pendidikan. Erlangga. Jakarta

Sari, A.K. (2014). Analisis Karakteristik Gaya BElajar VAK (Visual, Auditorial, Kinesterik) Mahasiswa Pendidikan Informatika Angkatan 2014. Jurnal Ilmiah Edutic/ Vol I, No. I Nopember 2014. ISSN 2407-4489. D i a $\mathrm{m} \mathrm{b}$ i 1 $\mathrm{d}$ a $\mathrm{r}$ i http\%3A\%2F\%2Fjournal.trunojoyo.ac.id 